This material is based upon work supported by the U.S. Department of Energy, Office of Science, Office of Fusion Energy Sciences, U.S. Department of Energy, under contract DE-AC05-00OR22725 with UT-Battelle, LLC, Fusion Energy Materials Program and Research supported by the Center for Nanophase Materials Sciences (CNMS), which is sponsored by the Scientific User Facilities Division, Office of Basic Energy Sciences, U.S. Department of Energy.

\title{
EVALUATION OF Pb-17Li COMPATIBILITY OF ODS Fe-12Cr-5Al ALLOYS
}

\author{
K.A. Unocic ${ }^{*}$ and D.T. Hoelzer \\ Oak Ridge National Laboratory, Oak Ridge, TN 37831, USA
}

\begin{abstract}
The Dual Coolant Lead Lithium (DCLL: eutectic $\mathrm{Pb}-17 \mathrm{Li}$ and $\mathrm{He}$ ) blanket concept requires improved $\mathrm{Pb}-17 \mathrm{Li}$ compatibility with ferritic steels in order to demonstrate acceptable performance in fusion reactors. As an initial step, static $\mathrm{Pb}-17$ at.\% $\mathrm{Li}(\mathrm{Pb}-17 \mathrm{Li})$ capsule experiments were conducted on new oxide dispersion strengthened (ODS) FeCrAl alloys ((1) $\mathrm{Y}_{2} \mathrm{O}_{3}$ (125Y), (2) $\mathrm{Y}_{2} \mathrm{O}_{3}+\mathrm{ZrO}_{2}$ (125YZ), (3) $\mathrm{Y}_{2} \mathrm{O}_{3}+\mathrm{HfO}_{2}(125 \mathrm{YH})$, and (4) $\mathrm{Y}_{2} \mathrm{O}_{3}+\mathrm{TiO}_{2}(125 \mathrm{YT})$ ) produced at $\mathrm{ORNL}$ via mechanical alloying (MA). Tests were conducted in static $\mathrm{Pb}-17 \mathrm{Li}$ for $1000 \mathrm{~h}$ at $700^{\circ} \mathrm{C}$. Alloys showed promising compatibility with $\mathrm{Pb}-17 \mathrm{Li}$ with small mass change after testing for $125 \mathrm{YZ}, 125 \mathrm{YH}$ and $125 \mathrm{YT}$, while the $125 \mathrm{Y}$ alloy experienced the highest mass loss associated with some oxide spallation and subsequent alloy dissolution. X-ray diffraction methods identified the surface reaction product as $\mathrm{LiAlO}_{2}$ on all four alloys. A small decrease $(\sim 1$ at.\%) in Al content beneath the oxide scale was observed in all 4 ODS alloys, which extended through $60 \mu \mathrm{m}$ beneath the oxide/metal interface. This indicates improvements in alloy dissolution by decreasing the amount of $\mathrm{Al}$ loss from the alloy. Scales formed on $125 \mathrm{YZ}, 125 \mathrm{YH}$ and $125 \mathrm{YT}$ were examined via scanning transmission electron microscopy (S/TEM) and revealed incorporation of $\mathrm{Zr}$-, Hf-, and Ti-rich precipitates within the $\mathrm{LiAlO}_{2}$ product, respectively. This indicates an inward scale growth mechanism. Future work in flowing $\mathrm{Pb}-17 \mathrm{Li}$ is needed to further evaluate the effectiveness of this strategy in a test blanket module.
\end{abstract}

Key words: Pb-17Li Compatibility, Cast FeCrAl, ODS FeCrAl, Mass change, Oxide Scale, $\mathrm{LiAlO}_{2}$

\section{Introduction}

The US leading blanket model for the ITER test blanket module (TBM) is the Dual Coolant Lead Lithium (DCLL: eutectic $\mathrm{Pb}-17 \mathrm{Li}$ liquid and $\mathrm{He}$ ) blanket concept. In order to demonstrate acceptable performance in fusion reactors [1-3] it requires improved $\mathrm{Pb}-17 \mathrm{at} . \% \mathrm{Li}(\mathrm{Pb}-17 \mathrm{Li})$ compatibility with ferritic steels. Current reduced activation ferritic-martensitic (FM) steels and 9Cr-ODS constrain the DCLL to $\sim 475^{\circ} \mathrm{C}$ due to rapid $\mathrm{Fe}$ and $\mathrm{Cr}$ dissolution in $\mathrm{Pb}-17 \mathrm{Li}$ ) above $\sim 500^{\circ} \mathrm{C}$ [4-12]. This compatibility issue is considered a key technological barrier for the DCLL 
concept. There are two strategies that are currently being investigated; (1) coating [13-18] and (2) alloying [19,20]. Both strategies rely upon the presence of Al to form a protective barrier (surface scale) against dissolution in $\mathrm{Pb}-17 \mathrm{Li}$. The first strategy was used to protect the base metal from dissolution in $[15,16,19,21,22]$; however, this concept did not provide an adequate solution above $600^{\circ} \mathrm{C}$ because it still did inhibit the dissolution of $\mathrm{Al}$ from the metal-oxide interface [17]. Moreover, above $600^{\circ} \mathrm{C}$, Al loss was not only due to the dissolution in $\mathrm{Pb}-17 \mathrm{Li}$ but also due to $\mathrm{Al} / \mathrm{N}$ interaction at the metal/coating interface, which was identified as a longterm issue that relates to microstructural evolution. For example, a thin $(\sim 50 \mu \mathrm{m}) \mathrm{Al}$ diffusion coating deposited via chemical vapor deposition (CVD) methods on Grade 92 steel evaluated for up to $5000 \mathrm{~h}$ at $600^{\circ}$ and $700^{\circ} \mathrm{C}$ showed promising mass loss reduction when compared with bare Grade 92 steel tested in $\mathrm{Pb}-17 \mathrm{Li}$ [14,19]; however, Al loss at the coating surface, was significant [19]. For the case of a thicker coating, which would have a significantly higher amount of Al reservoir, was not a suitable solution above $600^{\circ} \mathrm{C}$ and also showed a significant drop in the surface $\mathrm{Al}$ content [19], which in the long term can cause a problem due to Al reservoir depletion and subsequent inability to supply Al to the surface scale in order to maintain the barrier between the alloy and $\mathrm{Pb}-17 \mathrm{Li}$. At lower temperatures $\left(<500^{\circ} \mathrm{C}\right)$, specimens needed to be pre-oxidized in order to form a protective oxide layer regardless of the Al-rich coating system was used due to low solute diffusivities [21].

Another possibility was the alloying approach [19,20]. Pb-Li exposure experiments on model cast $\mathrm{FeCrAl}$ alloys suggested that using alloys with $\mathrm{Al}$ contents at or above $5 \mathrm{wt} \%$ minimized mass loss during exposure to $\mathrm{Pb}-17 \mathrm{Li}$ [19]. Compositions of 10-15 wt.\% $\mathrm{Cr}$ and 4.5-5 wt.\% $\mathrm{Al}$ showed promising behavior with the formation of a $\mathrm{LiAlO}_{2}$ surface layer during exposure in static $\mathrm{Pb}-17 \mathrm{Li}$ at $700^{\circ} \mathrm{C}$. This led to the development of oxide dispersion strengthened (ODS) Fe-12wt.\%Cr-5wt.\%Al alloys with similar composition to cast model alloys that would combine improved $\mathrm{Pb}-17 \mathrm{Li}$ compatibility with superior high-temperature mechanical properties and irradiation resistance.

Therefore, the aim of this study was to fabricate ODS FeCrAl with the compositions of 12 wt.\% $\mathrm{Cr}$ and 4.5-5 wt.\% $\mathrm{Al}$ and to evaluate their $\mathrm{Pb}-17 \mathrm{Li}$ compatibility. ODS FeCrAl alloys were exposed for $1000 \mathrm{~h}$ at $700^{\circ} \mathrm{C}$ in isothermal static $\mathrm{Pb}-17 \mathrm{Li}$ capsules as a preliminary evaluation prior to flowing $\mathrm{Pb}-17 \mathrm{Li}$ experiments and showed small mass change after exposures.

\section{Experimental}

In this study, four ODS FeCrAl alloys were produced with different oxide dispersions via mechanical alloying (MA): (1) $\mathrm{Y}_{2} \mathrm{O}_{3}$ (125Y) (2) $\mathrm{Y}_{2} \mathrm{O}_{3}+\mathrm{ZrO}_{2}$ (125YZ), (3) $\mathrm{Y}_{2} \mathrm{O}_{3}+\mathrm{HfO}_{2}$ $(125 \mathrm{YH})$, and (4) $\mathrm{Y}_{2} \mathrm{O}_{3}+\mathrm{TiO}_{2}(125 \mathrm{YT})$ with the compositions shown in Table 1. For comparison, two cast $\mathrm{FeCrAl}$ alloys $(\mathrm{Fe} 12 \mathrm{Cr} 5 \mathrm{Al})$ are also listed that were produced by arcmelting in inert gas (Ar) followed by water cooling of the $\mathrm{Cu}$ mold after casting. Detailed microstructural characterization of the ODS FeCrAl alloys after mechanical alloying revealed the 
presence of $\mathrm{Al}_{2} \mathrm{O}_{3}$ and yttrium aluminum garnet (YAG) phases $\left(\mathrm{Y}_{3} \mathrm{Al}_{5} \mathrm{O}_{12}\right)$ in the $125 \mathrm{Y}$ alloy, while in the $125 \mathrm{YZ}$ alloy additional $\mathrm{Zr}(\mathrm{C}, \mathrm{N})$ precipitates were discovered [23]. The $125 \mathrm{YH}$ alloy had the most complex precipitation sequence and in addition to $\mathrm{YAG}$ and $\mathrm{Al}_{2} \mathrm{O}_{3}$ phases, $\mathrm{Hf}(\mathrm{C}, \mathrm{N}), \mathrm{Y}_{2} \mathrm{Hf}_{2} \mathrm{O}_{7}$ and $\mathrm{HfO}_{2}$ precipitates were also found. Detailed characterization of the $125 \mathrm{YT}$ alloy is still in progress.

For exposure in static $\mathrm{Pb}-17 \mathrm{Li}$ specimens $\left(\sim 1.5 \mathrm{~mm}\right.$ thick and $\left.\sim 4-5 \mathrm{~cm}^{2}\right)$ were polished to a 600 grit $\mathrm{SiC}$ finish. All specimens were cleaned ultrasonically in acetone and alcohol and their mass was recorded before and after $\mathrm{Pb}-17 \mathrm{Li}$ exposure, using a Mettler-Toledo model XP205 balance with an accuracy of $\pm 0.04 \mathrm{mg}$.

Static capsule tests were performed using Mo (inert to $\mathrm{Pb}-17 \mathrm{Li}$ ) inner welded closed capsules and type 304 stainless steel (SS) outer capsules to protect the inner capsule from oxidation $[17,19]$. One specimen was exposed in each capsule and held with $1 \mathrm{~mm}$ diameter Mo wire. The capsules were loaded with $125 \mathrm{~g}$ of $\mathrm{Pb}-17 \mathrm{Li}$ in an Ar-filled $\left(<10 \mathrm{ppm} \mathrm{O}_{2}\right.$ and $<1 \mathrm{ppm}_{2} \mathrm{O}$ ) glove box. The $\mathrm{Pb}-17 \mathrm{Li}$ was purchased from $\mathrm{GMH}$ Stachow-Metall GmbH, Germany, with $\mathrm{Li}$ content of $0.68+/-0.01$ wt.\% (17.0 at.\%). Other elements such as Al, Cr, Fe, Mn, Mo, Ni, Si, Ti, $\mathrm{Y}, \mathrm{Zr}, \mathrm{S}, \mathrm{N}$ were less than detection limits in 1-10 wppm range. Average O level was $1200 \mathrm{wppm}$ (range 540-2400), while average $C$ content was 240 wppm (range 130-420). In this test cast Pb17Li at ORNL was also used with 200-400 ppmw of O. The Mo and SS capsules were welded shut within an argon glove box to prevent the uptake of impurities during the isothermal exposure carried out in a resistively heated box furnace. After exposure in $\mathrm{Pb}-17 \mathrm{Li}$, residual $\mathrm{Pb}-$ 17Li on the specimen surface was removed by soaking in a 1:1:1 mixture of acetic acid, hydrogen peroxide and ethanol for up to $72 \mathrm{~h}$, followed by cleaning in methanol.

Post-test specimen surfaces were examined using x-ray diffraction (XRD), scanning electron microscopy (SEM) imaging combined with energy dispersive $\mathrm{X}$-ray spectroscopy (EDS) analyses for chemical analysis. After surface characterization, the specimens were sectioned, polished and examined by light microscopy and electron probe microanalysis (EPMA) using wavelength dispersive X-ray analysis. The analyzed results from the ODS FeCrAl alloys were compared with the cast FeCrAlY alloys containing 12Cr-5Al-0.06Y in wt.\%. Detailed characterization of selected surface oxides formed during the $\mathrm{Pb}-17 \mathrm{Li}$ experiments was also carried out using scanning transmission electron microscopy (S/TEM) and EDS analysis using a Philips model CM200 scanning-transmission electron microscope equipped with a Schottky field emission gun (FEG) and EDAX system operated at $200 \mathrm{kV}$. The specimens for S/TEM analysis were prepared via the in situ lift-out method using the focused ion beam (FIB) milling technique using Hitachi NB5000 FIB-SEM.

\section{Results and Discussion}


The mass change data for the four ODS FeCrAl alloys (125Y, 125YZ, 125YH (repeat), 125YT) exposed in $\mathrm{Pb}-17 \mathrm{Li}$ for 1000 hours at $700^{\circ} \mathrm{C}$ are summarized in the bar plot shown in Figure 1. For reference, the mass change results for the cast $\mathrm{FeCrAl}$ alloys $(\mathrm{Fe} 12 \mathrm{Cr} 5 \mathrm{Al}=125 \mathrm{Y})[13]$, the 14YWT (ODS Fe-Cr) ferritic alloy [17] and the commercial PM2000 (ODS FeCrAl) alloy were also included (Tab. 1). Minimal mass change was observed for ODS FeCrAl alloys containing Y and either Zr, Hf or Ti elements. ODS FeCrAl alloy with only Y showed significantly higher mass loss. Two scenarios could account for the $125 \mathrm{Y}$ results; (1) the oxygen level within the alloy and/or (2) reactive elements (REs). All three $125 \mathrm{YT}, 125 \mathrm{YH}$ and $125 \mathrm{YZ}$ had higher $\mathrm{O}$ content than $125 \mathrm{Y}$ (Table 1), which may reflect that more of the Al was tied up as fine $\sim 3 \mathrm{~nm}$ oxides $\left(\mathrm{Y}_{3} \mathrm{Al}_{5} \mathrm{O}_{12}\right.$ (YAG phase)) in these alloys than in $125 \mathrm{Y}$ alloy. It can be hypothesize that small Al-rich oxides act as a reservoir for Al, since they are uniformly distributed throughout the matrix to form a surface oxide. Thus, the amount of these nano-sized oxides to support surface oxide would be reduced in $125 \mathrm{Y}$. In terms of reactive elements, previous research [24,25] on high-temperature oxidation has shown that in order to improve oxidation behavior of the material, co-doping (more than one) of reactive elements is more desired than a single doping, which is evident in this study. The three alloys $125 \mathrm{YT}, 125 \mathrm{YH}$, and $125 \mathrm{YZ}$ in addition to $\mathrm{Y}$, also contained second element such as $\mathrm{Ti}$, Hf or $\mathrm{Zr}$, respectively. In general, REs improve hightemperature oxidation by slowing down the oxide growth, improving scale adhesion, and decreasing the possibility of scale spallation. The highest mass loss was recorded for the $125 \mathrm{Y}$ specimen and linked to the spallation of the surface oxide and also to the presence of deep pits $(\sim 300 \mu \mathrm{m})$ at the surface (Fig. 2) associated with material dissolution in $\mathrm{Pb}-17 \mathrm{Li}$ due to absence of protective barrier (surface oxide). This suggests that the scale was not adherent or might be damaged. In terms of pits, alloy powder with little or no Al might be incorporated in these local areas of mechanically alloyed material, which was unable to reform a protective film after spallation, and therefore, material was selectively dissolved from the specimen. EPMA results generated beneath the pit (solid line, Fig. 2) showed a large Al content drop from $~ 9$ at.\% measured in the bulk alloy to 3.5 at.\% measured beneath the pit, which supports low Al level in these areas. This also shows that the Al level needs to be higher than 3.5 at.\% to reform protective surface layer, which supports our previous results [19], in order to prevent dissolution of the steel. Nevertheless, the small mass change of three ODS FeCrAl (125YZ, 125YH and $125 \mathrm{YT}$ ) alloys was consistent with the cast FeCrAl alloys of similar composition (Fig. 2/Tab. 1) confirming the beneficial effect of the presence of more than one reactive element in the alloy in addition to higher Al content. Regarding the different microstructures, the fine-grain structure in ODS alloys versus large grains in the cast alloy (cast 125Y) does not seem to have an effect on the dissolution rate, as was found by Li et al. $[10,11]$ in Al-free 9Cr-ODS alloy.

In all alloys containing $\mathrm{Al}$, the XRD analysis indicated the presence of the $\mathrm{LiAlO}_{2}$ layer and with the grazing incidence setup the x-ray penetration depth of $\mathrm{LiAlO}_{2}$ (scale thickness) was estimated to be around $3 \mu \mathrm{m}$. This corrosion product $\left(\mathrm{LiAlO}_{2}\right.$ layer) was formed [17] from $\mathrm{O}$ impurities in the $\mathrm{Pb}-17 \mathrm{Li}$ (200-400 ppmw of $\mathrm{O}$ in as-cast ORNL $\mathrm{Pb}-17 \mathrm{Li}$; average $\mathrm{O}$ level of 1200 ppmw in $\mathrm{Pb}-17 \mathrm{Li}$ purchased from Germany). Even though $\mathrm{Al}_{2} \mathrm{O}_{3}$ was not formed/detected, $\mathrm{LiAlO}_{2}$ layer still acted as an advantageous barrier for decreasing/preventing alloy dissolution into the liquid metal [26]. The benefit of the Al presence in ODS FeCrAl alloys can be clearly 
seen when mass changes of ODS FeCrAl alloys are compared with the ODS Fe-Cr alloy (14YWT) (Tab. 1) for which the highest mass loss $\left(2.9 \mathrm{mg} / \mathrm{cm}^{2}\right)$ was recorded (Fig. 1) [14,17]. Both $\mathrm{Fe}$ and $\mathrm{Cr}$ have a high solubility in $\mathrm{Pb}-17 \mathrm{Li}$, and without presence of $\mathrm{Al}$ to form a stable oxide, dissolution occurs rapidly. The dissolution rate decreases, when the liquid reaches saturation [14]. The commercial ODS alloy, PM2000, had a smaller mass loss $\left(\sim 0.2 \mathrm{mg} / \mathrm{cm}^{2}\right)$ than 14YWT due to the presence of $\mathrm{Al}$ in the alloy, resulting in the formation of a surface scale, which protects the alloy from the external environment. However, PM2000 showed poorer performance than the other three ODS FeCrAl alloys (Fig. 1). One reason could be alloy chemistry and the difference in precipitation type and their distribution. PM2000 contains mainly $\mathrm{Y}$ as a dopant with minor addition of Ti. As previously mentioned, in order to improve oxidation behavior co-doping is more favorable over single doping with the careful selection of the reactive elements [25,27]. Combination of $\mathrm{Y}$ and $\mathrm{Ti}$ is less effective [27] than combination of $\mathrm{Y}$ and $\mathrm{Hf}$ or $\mathrm{Y}$ and $\mathrm{Zr}$. On the contrary, the cast $125 \mathrm{Y} \mathrm{FeCrAl}$ alloy with an amount of $\mathrm{Cr}$ (12 wt.\%) and $\mathrm{Al}$ (5 wt.\%) similar to ODS FeCrAl alloys had a comparable mass change to the ODS $\mathrm{FeCrAl}$ alloys even though it contained only one reactive element (Y). This shows that there must be other factors in addition to REs such as either uniform distribution of YAG phase in ODS FeCrAl or oxygen level affecting $\mathrm{Pb}-17 \mathrm{Li}$ compatibility that requires further investigation. The higher oxygen level in PM2000, which was much higher (8056 ppma) than in ODS FeCrAl (<7500 ppma), could affect the oxide precipitation and Al distribution.

It should be mentioned that the $125 \mathrm{YH}$ specimen was tested twice in $\mathrm{Pb}-17 \mathrm{Li}$. Surprisingly, the first results showed similar high mass loss to the $125 \mathrm{Y}$ specimen [20]. There was no indication of significant alloy dissolution but spallation near the specimen edges was observed. This could be either due to the specimen preparation for the test, the oxygen level in $\mathrm{Pb}-17 \mathrm{Li}$ (first test was preformed with ORNL Pb-17Li (200-400 ppmw of O) while second $\mathrm{Pb}-17 \mathrm{Li}$ exposure/test with $\mathrm{Pb}-17 \mathrm{Li}$ purchased from Germany (1200 ppmw of $\mathrm{O})$ ), or non-uniform distribution of elements throughout the material near the surface in the alloy due to mechanical alloying. Nevertheless, the second exposure in $\mathrm{Pb}-17 \mathrm{Li}$ was run with additional care during specimen preparation (grinding with $\mathrm{SiC}$ ) and as shown in Figure 1 the mass change was small and comparable with mass losses to alloy $125 \mathrm{YZ}$ and $125 \mathrm{YT}$.

Metallographic cross-sections were prepared from the specimens after exposure to $\mathrm{Pb}-17 \mathrm{Li}$ to investigate surface scales that were supposed to be a barrier to prevent dissolution of the material in $\mathrm{Pb}-17 \mathrm{Li}$ and to compare their morphology with scales formed on the cast $125 \mathrm{Y}$, commercial PM2000 and 14YWT alloys (Tab. 1). The metallographic cross-sections are shown in Figure 3. A thin $(1.5-3 \mu \mathrm{m})$ scale can be observed in all Al containing alloys, while in 14YWT (ODS Fe-Cr alloy) a thick $19.8 \pm 3.7 \mu \mathrm{m}$ "interaction layer" was found. However, this layer was not an oxide but it was mixture of $\mathrm{Pb}-17 \mathrm{Li}$ and alloy, which was like a "sponge" filled with $\mathrm{Pb}$ (detected by EPMA). This suggests penetration of the liquid $\mathrm{Pb}-17 \mathrm{Li}$ into the solid structure without suitable protective barrier [7,9,28,29] and alloy dissolution (mass loss of 14YWT Fig. 1) of the base metal showing the importance of its presence.

Due to the metallographic mounting almost all of the scales were detached from the substrates. This introduced challenges in analyzing elemental segregation and thickness of the scale cross- 
sections via either light microscopy or SEM. However, evaluation of the elemental depletion beneath the exposed oxide/metal interface via EPMA is still valid, and it was carried out. The EPMA results for normalized $\mathrm{Al}$ and $\mathrm{Cr}$ elements for the $125 \mathrm{Y}, 125 \mathrm{YZ}, 125 \mathrm{YH}, 125 \mathrm{YT}$ specimens are plotted in Figure 4. For comparison, EPMA results from the cast $125 \mathrm{Y}$ and PM2000 alloys are also included. For the 125YT specimen, there was no variation in $\mathrm{Al}$ content ( $~ 9$ at.\%) and only a slight change in $\mathrm{Cr}$ level (from 12 to 11.5 at.\%) at the oxide/metal interface with a small $\mathrm{Cr}$ depletion reaching about $4 \mu \mathrm{m}$ depth beneath the interface. For the other three ODS FeCrAl specimens (125Y, $125 \mathrm{YH}$ and $125 \mathrm{YZ})$, a small drop in Al content at the oxide/metal interface was observed extending through about $60 \mu \mathrm{m}$ depth beneath the interface. In all three alloys measured $\mathrm{Al}$ level in the bulk was 8.5 at.\% and decreased to 8.0 at.\% at the oxide/metal interface for $125 \mathrm{Y}, \sim 7.75 \pm 0.4$ at. $\%$ for $125 \mathrm{YH}$ and $7.4 \pm 0.1$ at. $\%$ for $125 \mathrm{YZ}$. The $\mathrm{Cr}$ depletion depth of $\sim 4 \mu \mathrm{m}$ was similar among these three ODS FeCrAl alloys and was comparable with the $\mathrm{Cr}$ depletion depth found in $125 \mathrm{YT}$. In alloy $125 \mathrm{YH}$ and $125 \mathrm{YZ}$, there was a drop in Cr content of 0.5 at.\% between location measured in the bulk (12 at.\%) and at the oxide/metal interface (11.5 at.\%), while 1 at.\% drop in $\mathrm{Cr}$ was measured for $125 \mathrm{Y}$ alloy at the oxide/metal interface. Comparing results with the cast 125Y and PM2000 alloy, it was found that the Al depletion depth was similar $(\sim 60 \mu \mathrm{m})$ to ODS FeCrAl alloys with Al content drop of 1 at.\%. A larger $(\sim 10 \mu \mathrm{m})$ Cr depletion depth with a drop of 1 at. $\%$ was found for cast $125 \mathrm{Y}$ alloy, while no variation in $\mathrm{Cr}$ concentration was found in PM2000 beneath the oxide/metal interface. In Al-free ODS Fe-Cr alloy (14YWT), the drop in Cr concentration at the surface was about 3 at.\% (Fig. 5a) with the depth of $60 \mu \mathrm{m}$, which is similar to the depth for aluminum in Alcontaining alloys. Additionally in 14YWT, $\mathrm{C}$ depletion was found (Fig. 5b), which accompanied Cr depletion with its drop of 2 at.\% at the surface.

Detailed analysis of the cross section of the surface reaction products was not feasible from the bulk specimens exposed to $\mathrm{Pb}-17 \mathrm{Li}$ for $1000 \mathrm{~h}$ at $700^{\circ} \mathrm{C}$, due to oxide layer separation/detachment from the substrate during metallographic mounting (Fig. 3). Consequently, TEM specimens were prepared for $125 \mathrm{YT}, 125 \mathrm{YZ}$ and $125 \mathrm{YH}$ specimens using FIB-milling methods form the tops surface. An example of the bright-field (BF) and high-angle annular dark-field (HAADF) STEM images for alloy 125YZ are shown in Figures 6 and 7 (higher magnification). The scale thickness is approximately $1.36 \pm 0.2 \mu \mathrm{m}$ and it is continuous with some small separation at the oxide/metal interface. Similar separation at the interface was found on these alloys after exposure to steam at $1200^{\circ} \mathrm{C}$ for $4 \mathrm{~h}$ [20], which suggests it is alloy specific and not due to exposure to $\mathrm{Pb}-17 \mathrm{Li}$. It could be speculated that interface separation is most likely due to void (introduced during mechanical alloying) coalescence during hightemperature exposure. The oxide scale grains appeared to be columnar indicative of inner scale growth with a number of small voids throughout the scale incorporated during its growth. Additionally, precipitates were incorporated from the substrate throughout the scale, which additionally supports the inward scale growth mechanism. The scale itself was extremely beam sensitive and electron diffraction analysis was not possible due to the scale damage. Similar observation of $\mathrm{LiAlO}_{2}$ scale sensitivity under the beam was observed by Pint and More [26], which further supports the presence of $\mathrm{LiAlO}_{2}$, and is consistent with our XRD results. 
Figure 8 shows the oxide cross-section formed on $125 \mathrm{YT}$ after $1000 \mathrm{~h}$ testing in $\mathrm{Pb}-17 \mathrm{Li}$ at $700^{\circ} \mathrm{C}$. The scale thickness was $\sim 0.77 \pm 0.3 \mu \mathrm{m}$ and it also contained precipitates within the reaction product, which supports the inward scale growth mechanism. EDS point analysis indicated that these precipitates were mainly Ti-rich and no strong oxygen or Y concentration was detected along with Ti signal generated from the precipitates. Advanced electron diffraction analysis of these precipitates was not possible due to electron beam damage of the oxide. Atom probe tomography (APT) attempts are in progress to help identify these precipitates, to investigate if there is a higher Li concentration associated with the precipitates found in the scale, and to determine if they are still oxides.

STEM was used to examine the $125 \mathrm{YH}$ specimen exposed to static $\mathrm{Pb}-17 \mathrm{Li}$ for $1000 \mathrm{~h}$ at $700^{\circ} \mathrm{C}$, and an example of the oxide cross-section is shown in Figure 9. The scale thickness was $\sim 0.65 \pm$ $0.1 \mu \mathrm{m}$ and some of the $\mathrm{Pb}-17 \mathrm{Li}$ remnant was still present on the scale even after 72 hours of cleaning/soaking soaking in a 1:1:1 mixture of acetic acid, hydrogen peroxide and ethanol. Within the scale, precipitates were also observed and EDS analysis showed mainly Hf enrichment without any strong oxygen or yttrium signal concentration suggesting $\mathrm{Hf}(\mathrm{C}, \mathrm{N})$. The reaction product was mainly single layer with columnar grains throughout the entire scale thickness. Both the columnar grains and incorporated Hf-rich precipitates support an inward scale growth mechanism. However, the scale appearance is rather different than it is generally observed in the high-temperature testing in various gas media suggesting of some differences in the mechanism of scale growth between liquid and gas media at high temperature. In the scales formed in gas media, for instance in $100 \% \mathrm{H}_{2} \mathrm{O}$ (steam) [20], usually the oxide precipitates from the alloy are not incorporated, which was found in scales formed during $\mathrm{Pb}-17 \mathrm{Li}$ testing. If the oxide precipitates are found in the scale, they are mainly located along oxide grain boundaries and at the triple points due to the outward diffusion of reactive elements along scale grain boundaries. On the contrary, similar precipitate distribution and incorporation throughout the scale was found after testing of $\mathrm{Mg}$ alloys in salt water [30]. This suggests and supports the notion that even though the scale growth is inward in the liquid media, it is still different than in the gas media and requires further investigation.

Based on the results, it can be seen that the previous prediction of the composition established on the cast specimens was a helpful strategy that allowed narrowing down the composition of the ODS FeCrAl alloys and reduced the cost of the evaluation process. Three out of the four of the ODS FeCrAl alloys produced at ORNL [24] showed promising compatibility with $\mathrm{Pb}-17 \mathrm{Li}$ with small mass change after testing for $1000 \mathrm{~h}$ at $700^{\circ} \mathrm{C}$ in static $\mathrm{Pb}-17 \mathrm{Li}$. This alloying strategy only addresses compatibility in static testing and the new ODS FeCrAl alloys will be evaluated next in flowing $\mathrm{Pb}-17 \mathrm{Li}$ experiments. It should be mentioned that this alloying strategy only addresses $\mathrm{Pb}-17 \mathrm{Li}$ compatibility and does not address tritium control nor provide a solution to the magneto-hydrodynamic pressure drop [31]. 


\section{Conclusions}

Static $\mathrm{Pb}-17 \mathrm{Li}$ capsule experiments were conducted to evaluate new ODS FeCrAl alloys ((1) $\mathrm{Y}_{2} \mathrm{O}_{3}$ (125Y), (2) $\mathrm{Y}_{2} \mathrm{O}_{3}+\mathrm{ZrO}_{2}$ (125YZ), (3) $\mathrm{Y}_{2} \mathrm{O}_{3}+\mathrm{HfO}_{2}(125 \mathrm{YH})$, and (4) $\mathrm{Y}_{2} \mathrm{O}_{3}+\mathrm{TiO}_{2}(125 \mathrm{YT})$ ) produced at ORNL via mechanical alloying (MA) to improve $\mathrm{Pb}-17 \mathrm{Li}$ compatibility of Fe-base alloys above $600^{\circ} \mathrm{C}$. Tests were conducted in static $\mathrm{Pb}-17 \mathrm{Li}$ for $1000 \mathrm{~h}$ at $700^{\circ} \mathrm{C}$. Alloys showed promising compatibility with $\mathrm{Pb}-17 \mathrm{Li}$ with small mass change after testing for $1000 \mathrm{~h}$ at $700^{\circ} \mathrm{C}$ in static $\mathrm{Pb}-17 \mathrm{Li}$ for $125 \mathrm{YZ}, 125 \mathrm{YH}$ and $125 \mathrm{YT}$, while $125 \mathrm{Y}$ alloy experienced the highest mass loss associated with spallation of the oxide and dissolution of the substrate. XRD methods identified the surface reaction product as $\mathrm{LiAlO}_{2}$ in all four alloys. Al depletion was observed beneath exposed surfaces in all 4 ODS alloys, with an Al drop of $\sim 1$ at.\% at the surface. Scales formed on $125 \mathrm{YZ}, 125 \mathrm{YH}$ and $125 \mathrm{YT}$ were examined via STEM and showed Zr-, Hf-, and Tirich precipitates incorporated throughout the $\mathrm{LiAlO}_{2}$ product, respectively, with an identified inward scale growth mechanism. The next step will be to evaluate the new ODS FeCrAl alloys in flowing $\mathrm{Pb}-17 \mathrm{Li}$ experiments.

\section{Acknowledgments}

Research sponsored by the U.S. Department of Energy (DOE), Office of Fusion Energy Sciences, U.S. Department of Energy, under contract DE-AC05-00OR22725 with UT-Battelle, LLC, Fusion Energy Materials Program and Research supported by Oak Ridge National Laboratory's Center for Nanophase Materials Sciences (CNMS), a U.S. Department of Energy Office of Science User Facility. T.M. Lowe, M.S. Stephens, T.S. Geer, D.W. Coffey and D.N. Leonard assisted with the experimental work. L.F. Allard, D.A. Cullen and S. Pawel provided comments on the results and manuscript.

\section{References}

[1] M. Abdou, D. Sze, C. Wong, M. Sawan, A. Ying, N.B. Morley, et al., U.S. Plans and Strategy for ITER Blanket Testing, Fusion Science and Technology. 47 (2005) 475-487.

[2] C.P.C. Wong, J.F. Salavy, Y. Kim, I. Kirillov, E.R. Kumar, N.B. Morley, et al., Overview of liquid metal TBM concepts and programs, Journal of Nuclear Materials. 83 (2008) 850-857.

[3] C.P.C. Wong, S. Malang, M. Sawan, M. Dagher, S. Smolentsev, B. Merrill, et al., An overview of dual coolant $\mathrm{Pb}-17 \mathrm{Li}$ breeder first wall and blanket concept development for the US ITER-TBM design, Fusion Engineering and Design. 81 (2006) 461-667.

[4] J. Konys, W. Krauss, J. Novotny, H. Steiner, Z. Voss, O. Wedemeyer, Compatibility behavior of EUROFER steel in flowing Pb-17Li, Journal of Nuclear Materials. 386-388 (2009) 678-681.

[5] P.F. Tortorelli, J.H. Devan, Compatibility of stainless steel with Pb-17 At. Pct Li, Journal of Materilas for Energy Systems. 4 (1982) 78-83.

[6] J. Konys, W. Krauss, Z. Voss, O. Wedemeyer, Corrosion behavior of EUROFER steel in flowing eutectic Pb-17Li alloy, Journal of Nuclear Materials. 329-333 (2004) 13791383. 
[7] O.K. Chopra, D.L. Smith, Corrosion Behavior of Vanadium Alloys in Flowing Lithium, Journal of Nuclear Materials. 155-157 (1988) 683-689.

[8] G. Müller, A. Heinzel, J. Konys, G. Schumacher, A. Weisenburger, F. Zimmermann, et al., Results of steel corrosion tests in flowing liquid $\mathrm{Pb} / \mathrm{Bi}$ at $420-600{ }^{\circ} \mathrm{C}$ after $2000 \mathrm{~h}$, Journal of Nuclear Materials. 301 (2002) 40-46.

[9] H. Glasbrenner, J. Konys, H.D. Röhrig, K. Stein-Fechner, Z. Voss, Corrosion of ferriticmartensitic steels in the eutectic Pb-17Li, Journal of Nuclear Materials. 283-287 (2000) 1332-1335.

[10] Y.F. Li, M. Kondo, T. Nagasaka, T. Muroga, V. Tsisar, Influence of Exposure to Pb-Li on Microstructure and Mechanical Properties of 9Cr-ODS and CLAM Steels, Fusion Science and Technology. 60 (2011) 359-363.

[11] Y. Li, H. Abe, T. Nagasaka, T. Muroga, M. Kondo, Corrosion behavior of 9Cr-ODS steel in stagnant liquid lithium and lead-lithium at 873K, Journal of Nuclear Materials. 443 (2013) 200-206.

[12] J. Konys, W. Krauss, Z. Zhu, Q. Huang, Comparison of corrosion behavior of EUROFER and CLAM steels in flowing Pb-15.7Li, Journal of Nuclear Materials. 455 (2014) 491-495.

[13] W. Krauss, J. Konys, S.-E. Wulf, Corrosion barriers processed by Al electroplating and their resistance against flowing $\mathrm{Pb}-15.7 \mathrm{Li}$, Journal of Nuclear Materials. 455 (2014) 522-526.

[14] B.A. Pint, K.A. Unocic, Pb-Li compatibility issues for DEMO, Journal of Nuclear Materials. 442 (2013) S572-S575.

[15] B.A. Pint, The effect of coatings on the compatibility of $\mathrm{Fe}-\mathrm{Cr}$ steels with $\mathrm{Pb}-\mathrm{Li}$, Journal of Nuclear Materials. 417 (2011) 1195-1199.

[16] B.A. Pint, J.L. Moser, P.F. Tortorelli, Investigation of Pb-Li compatibility issues for the dual coolant blanket concept, Journal of Nuclear Materials. 367-370 (2007) 1150-1154.

[17] B.A. Pint, L.R. Walker, K.A. Unocic, Material compatibility with isothermal Pb-Li, Materials at High Temperatures. 29 (2012).

[18] H. Glasbrenner, Z. Peric, H.U. Borgstedt, Alloying of aluminum and its influence on the properties of aluminide coatings: oxidation behavior and the chemical stability in Pb17Li, Journal of Nuclear Materials. 233-237 (1996) 1378-1382.

[19] K.A. Unocic, B.A. Pint, Alloying and coating strategies for improved Pb-Li compatibility in DEMO-type fusion reactors, Journal of Nuclear Materials. 455 (2014) 330-334.

[20] K.A. Unocic, D.T. Hoelzer, B.A. Pint, Microstructure and environmental resistance of low Cr ODS FeCrAl, Materials at High Temperatures. 32 (2015) 123-132.

[21] H. Glasbrenner, J. Konys, Z. Voss, O. Wedemeyer, Corrosion behaviour of Al based tritium permeation barriers in flowing $\mathrm{Pb}-17 \mathrm{Li}$, Journal of Nuclear Materials. 307-311 (2002) 1360-1363.

[22] B. Pint, Overview of coating and compatibility research for Fusion Energy in the U.S, Materials Science Forum. 595-598 (2008) 549-558.

[23] K.A. Unocic, B.A. Pint, D.T. Hoelzer, Advanced TEM Characterization of Oxide Nanoparticles in ODS Fe-12Cr-5Al Alloys, Journal of Materials Science. Accepted 
(DOI: 10.1007/s10853-016-0111-5).

[24] B.A. Pint, Optimization of Reactive-Element Additions to Improve Oxidation Performance of Alumina-Forming Alloys, J. Am. Ceram. Soc. 86 (2003) 686-695.

[25] K.A. Unocic, B.A. Pint, Oxidation Behavior of Co-Doped NiCrAl Alloys in Dry and Wet Air, Surface \& Coatings Technology. 237 (2013) 8-15.

[26] B.A. Pint, K.L. More, Transformation of $\mathrm{Al}_{2} \mathrm{O}_{3}$ to $\mathrm{LiAlO}_{2}$ in $\mathrm{Pb}-17 \mathrm{Li}$ at $800^{\circ} \mathrm{C}$, Journal of Nuclear Materials. 376 (2008) 108-113.

[27] K.A. Unocic, D.N. Leonard, B.A. Pint, Effect of Boron on the Oxidation Behavior of NiCrAlYHfTi in $\mathrm{H}_{2} \mathrm{O}$ and $\mathrm{CO}_{2}$ Environments, Surface \& Coatings Technology. 260 (2014) 17-22.

[28] T. Sample, H. Kolbe, Liquid metal embrittlement (LME) susceptibility of the 8-9\% Cr martensitic steels F82H-mod., OPTIFER IVb and their simulated welded structures in liquid Pb-17Li, Journal of Nuclear Materials. 283-287 (2000) 1336-1340.

[29] A. Aiello, M. Agostini, G. Benamati, B. Long, G. Scaddozzo, Mechanical properties of martensitic steels after exposure to flowing liquid metals, Journal of Nuclear Materials. 335 (2004) 217-221.

[30] K.A. Unocic, H.H. Elsentriecy, M.P. Brady, H.M. Meyer III, G.L. Song, M. Fayek, et al., Transmission Electron Microscopy Study of Aqueous Film Formation and Evolution on Magnesium Alloys, Journal of the Electrochemical Society. 161 (2014) C302-C311.

[31] D. Naumenko, V. Kochubey, L. Niewolak, A. Dymiati, J. Mayer, L. Singheiser, et al., Modification of alumina scale formation on FeCrAlY alloys by minor additions of group IVa elements - Springer, Journal of Matererials Science. 43 (2008) 4550-4560.

\section{Figure Captions}

Figure 1. Mass change results for several alloys after capsule exposure in $\mathrm{Pb}-\mathrm{Li}$ for $1000 \mathrm{~h}$ at $700^{\circ} \mathrm{C}$.

Figure 2. EPMA results for normalized Al content (at.\%) generated from the pit/dissolved area $(0 \mu \mathrm{m})$ towards the alloy after exposure to $\mathrm{Pb}-\mathrm{Li}$ at $700^{\circ} \mathrm{C}$ for $1000 \mathrm{~h}$. For reference EPMA for regular exposed surface/area is also included (dash line).

Figure 3. BSE images of as-polished cross-sections of different alloys after exposure in static $\mathrm{Pb}-17 \mathrm{Li}$ for $1000 \mathrm{~h}$ at $700^{\circ} \mathrm{C}$.

Figure 4. EPMA results for Normalized a) $\mathrm{Al}$ and b) $\mathrm{Cr}$ content (at.\%) generated from the exposed surface $(0 \mu \mathrm{m})$ towards the alloy for different alloys after exposure to static $\mathrm{Pb}-17 \mathrm{Li}$ at $700^{\circ} \mathrm{C}$ for $1000 \mathrm{~h}$. 
Figure 5. EPMA results for Normalized a) $\mathrm{Cr}$ and b) $\mathrm{C}$ content (at.\%) generated from the exposed surface $(0 \mu \mathrm{m})$ towards the alloy for $14 \mathrm{YWT}$ alloy after exposure to static $\mathrm{Pb}-17 \mathrm{Li}$ at $700^{\circ} \mathrm{C}$ for $1000 \mathrm{~h}$.

Figure 6. a) HAADF and b) BF-STEM image of the final oxide cross-section formed on alloy $125 \mathrm{YZ}$ for $1000 \mathrm{~h}$ exposure at $700^{\circ} \mathrm{C}$ in static $\mathrm{Pb}-17 \mathrm{Li}$.

Figure 7. Higher magnification images of BF-STEM (a,c) and HAADF (b) of the oxide crosssection formed on $125 \mathrm{YZ}$ after $1000 \mathrm{~h}$ exposure at $700^{\circ} \mathrm{C}$ in static $\mathrm{Pb}-17 \mathrm{Li}$ with $\mathrm{EDS}$ point spectrum $(\mathrm{d})$ generated from particle within the oxide.

Figure 8. a) BF-STEM image and b) DF-STEM image of the oxide cross-section formed on $125 \mathrm{YT}$ during $1000 \mathrm{~h}$ exposure at $700^{\circ} \mathrm{C}$ in static $\mathrm{Pb}-17 \mathrm{Li}$. c) EDS elemental maps generated from Figure 8a.

Figure 9. a) BF-STEM image and b) HAADF-STEM image of the oxide cross-section formed on $125 \mathrm{YH}$ during $1000 \mathrm{~h}$ exposure at $700^{\circ} \mathrm{C}$ in static $\mathrm{Pb}-17 \mathrm{Li}$. c) and d) higher magnification images, respectively. Insert in Fig. 9c shows Ti EDS elemental map. 
Table 1. Chemical composition (at.\%) determined by Inductively Coupled Plasma Atomic Emission Spectroscopy (ICP-AES). Values for Y, O, N, C, S in ppma.

\begin{tabular}{cccccccccc}
\hline Material & Fe & Cr & Al & Y & N & C & S & O & Others \\
\hline Cast 105Y & 80.4 & 10.2 & 9.4 & 230 & 10 & 220 & 21 & 40 & \\
\hline Cast 125Y & 79.1 & 12.2 & 8.7 & 160 & 30 & 220 & 21 & 60 & $0.02 \mathrm{Si}$ \\
\hline 125Y & 78.3 & 11.5 & 9.3 & 1120 & 1710 & 1660 & 33 & 2760 & $0.04 \mathrm{Si}$ \\
\hline 125YH & 77.5 & 11.8 & 9.4 & 1010 & 410 & 960 & 16 & 7500 & $0.200 \mathrm{Hf}-0.006 \mathrm{Zr}$ \\
\hline 125YZ & 77.8 & 11.6 & 9.5 & 1060 & 600 & 1090 & 16 & 6290 & $0.003 \mathrm{Hf}-0.17 \mathrm{Zr}$ \\
\hline 125YT & 77.2 & 12.1 & 9.4 & 940 & 500 & 1520 & 49 & 7258 & $0.009 \mathrm{Hf}-0.02 \mathrm{Si}$ \\
\hline 14YWT & 83.25 & 14.07 & 0.04 & 1240 & 5166 & 3001 & 69 & 5997 & $0.585 \mathrm{~W}$ \\
\hline PM2000 & 68.97 & 19.12 & 10.5 & 2280 & 319 & 61 & 13 & 8056 & $\begin{array}{c}0.06 \mathrm{Mn}-0.02 \mathrm{Ni}- \\
0.03 \mathrm{P}-0.04 \mathrm{Si}- \\
0.52 \mathrm{Ti}\end{array}$ \\
\hline
\end{tabular}




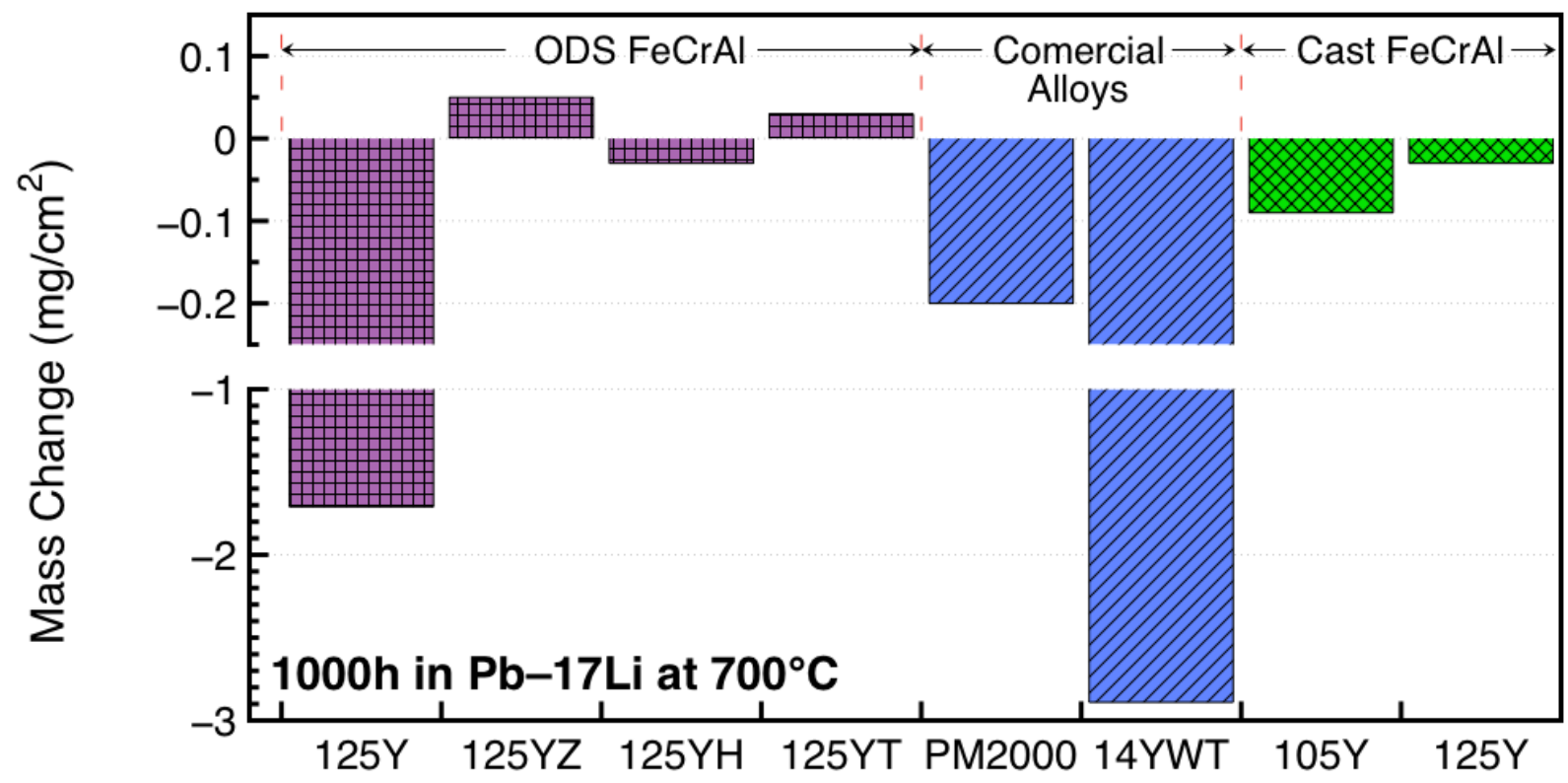

Figure 1.

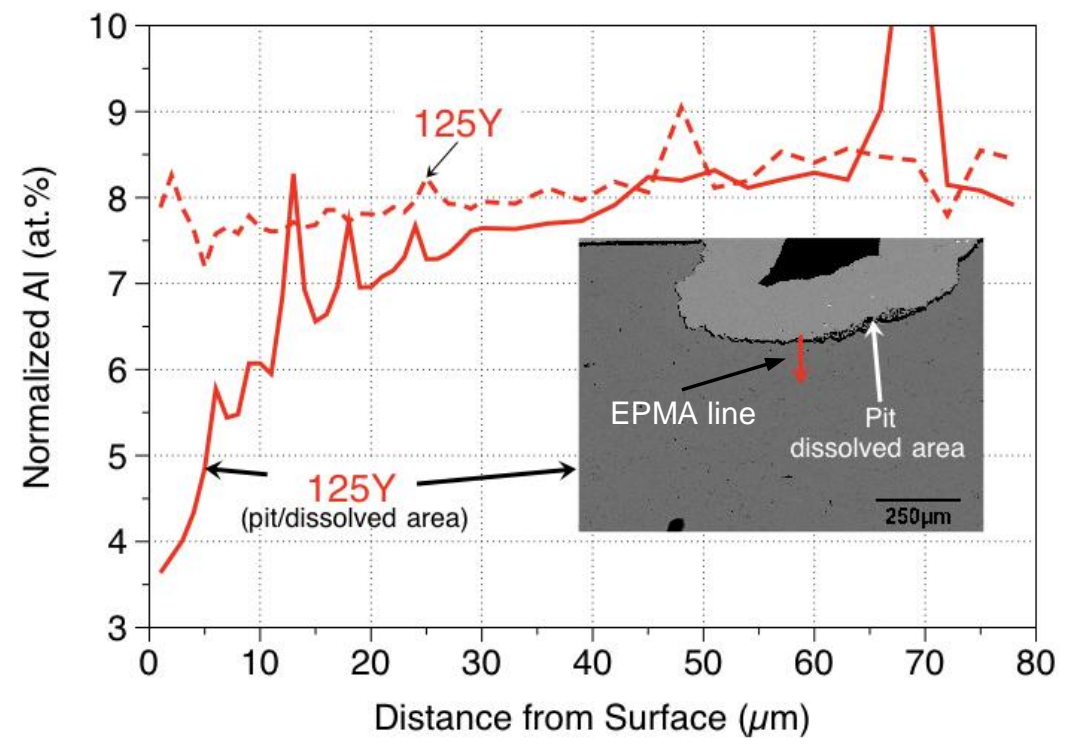

Figure 2. 


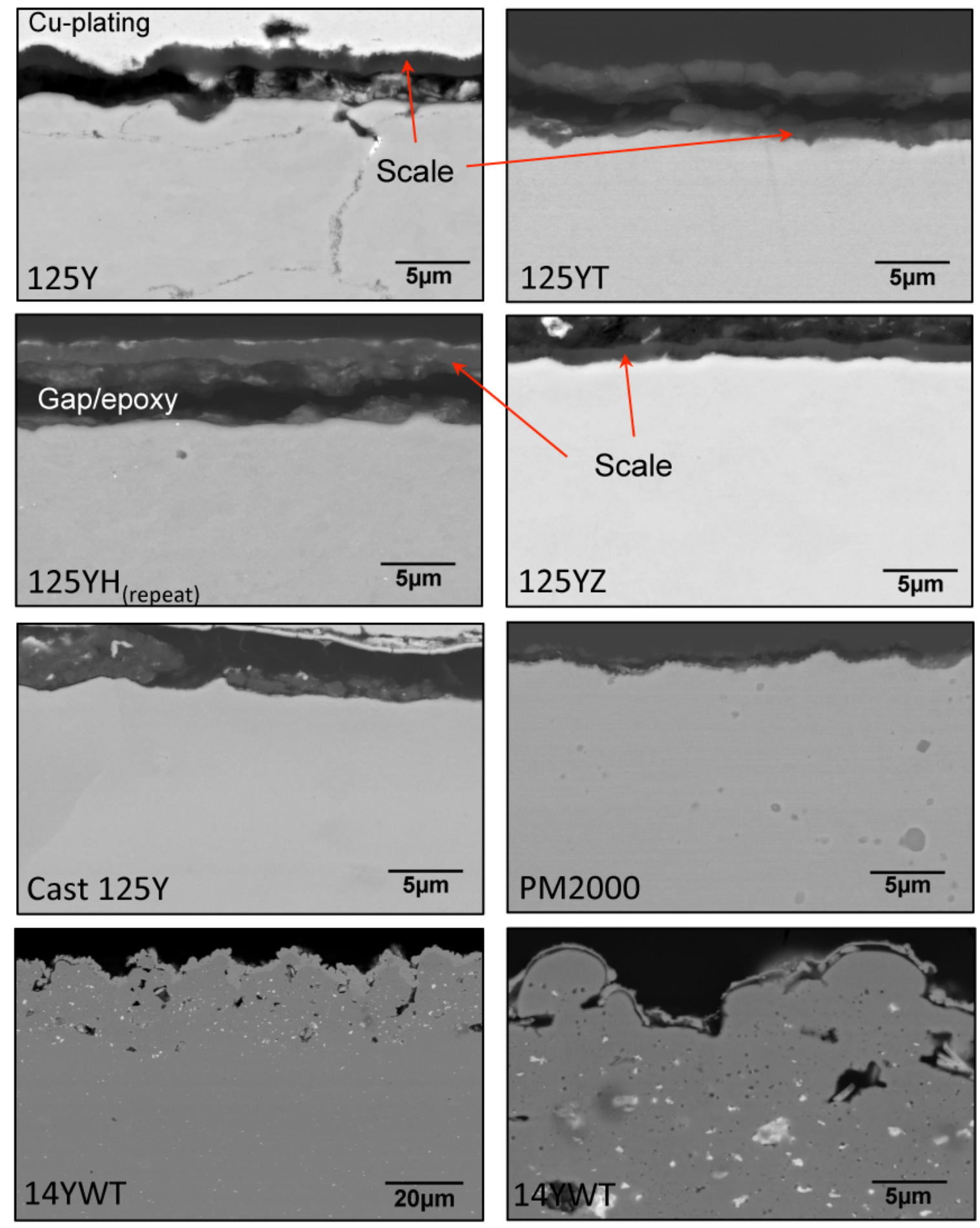

Figure 3. 

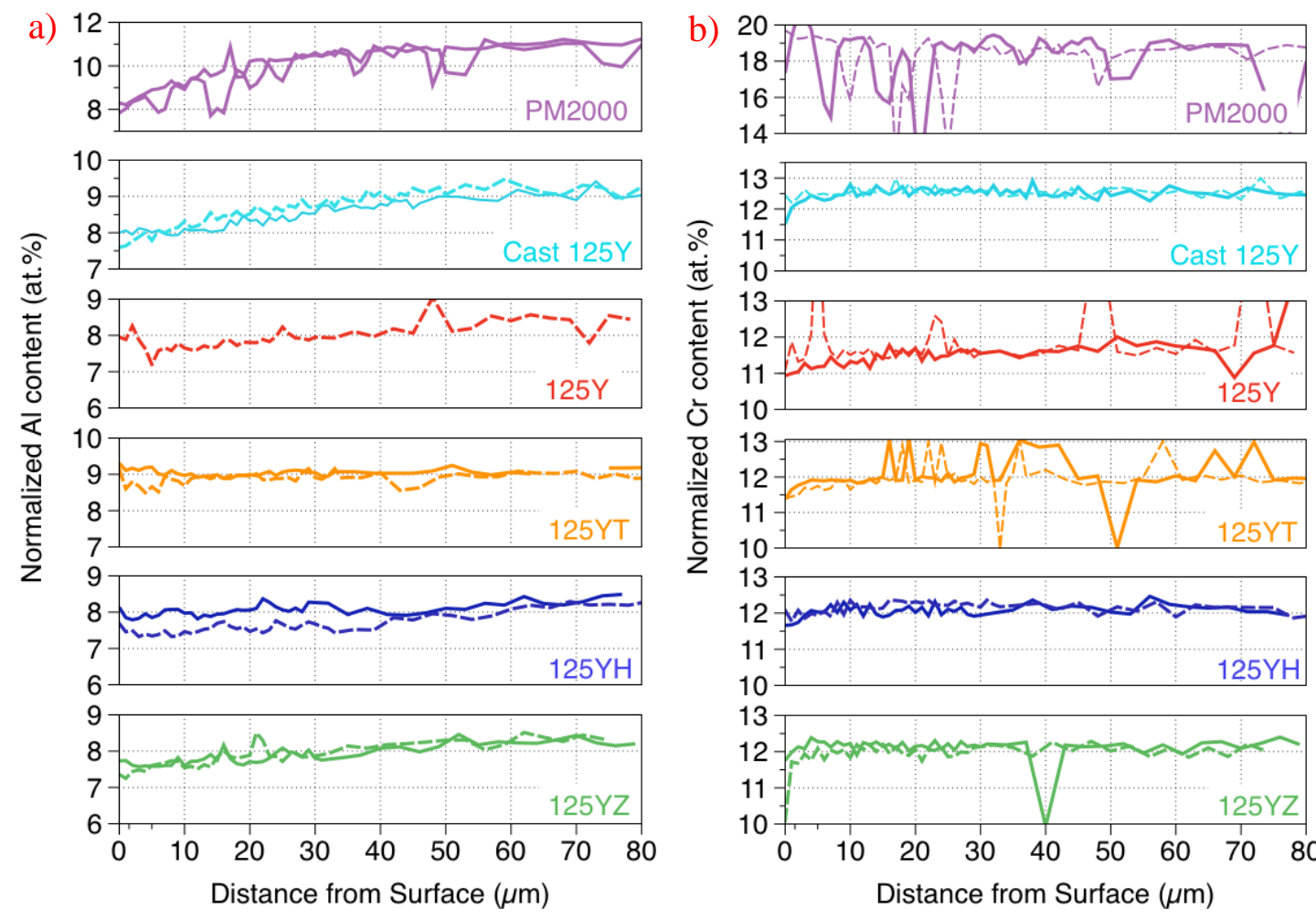

Figure 4.

a)

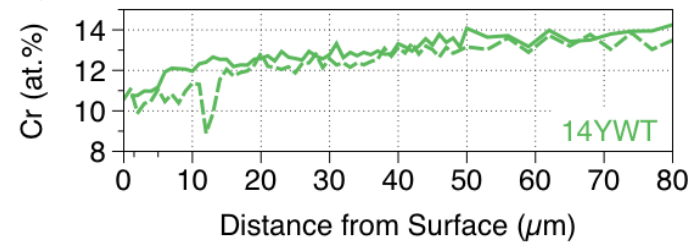

Figure 5. b)

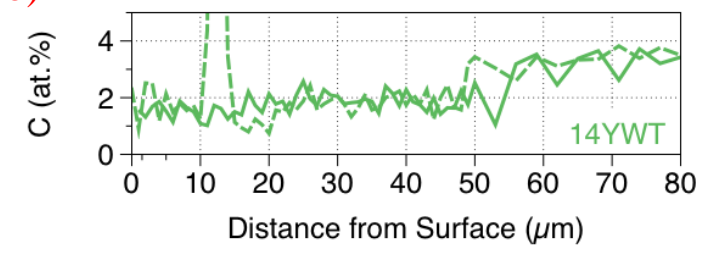



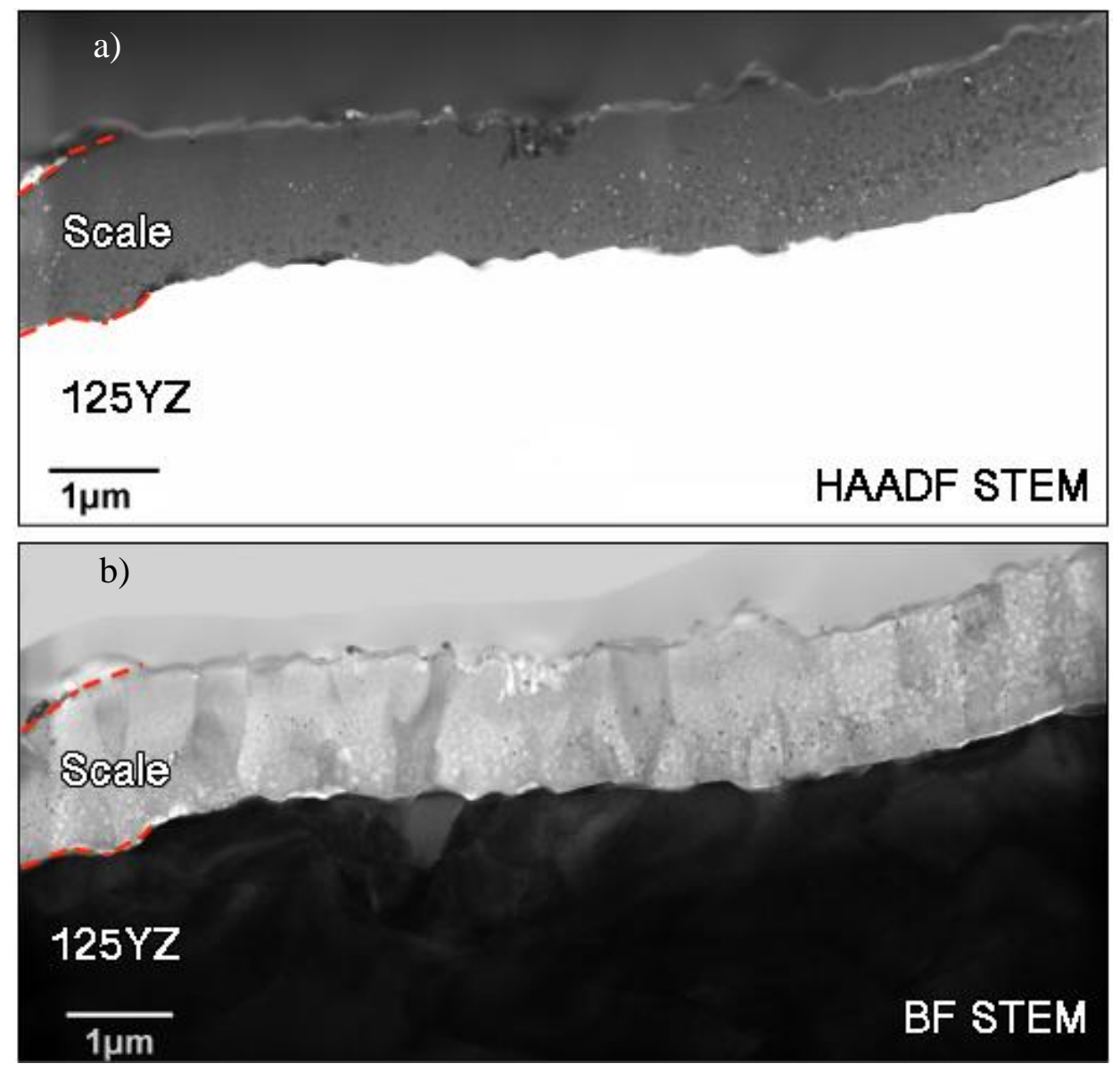

Figure 6. 

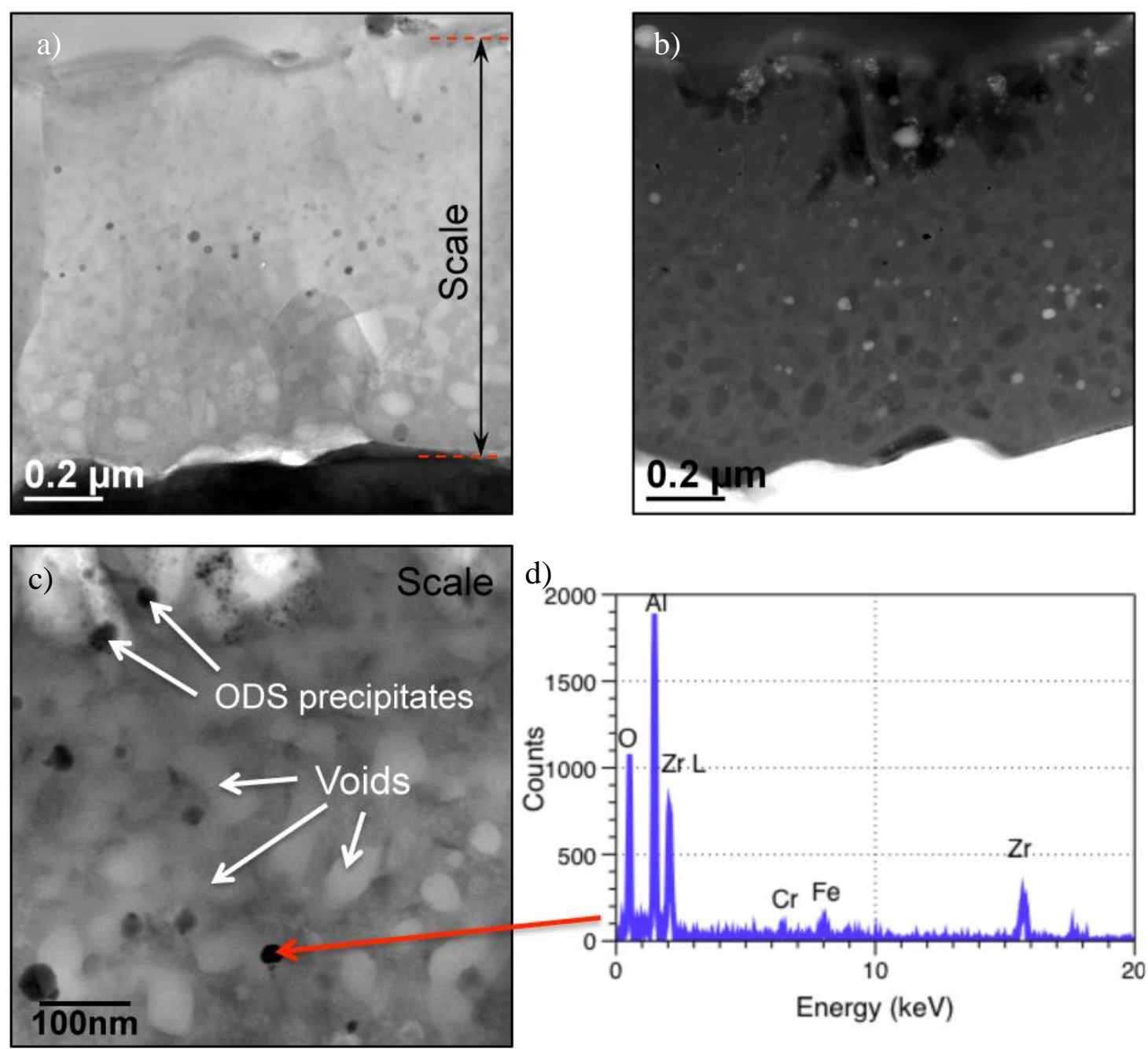

Figure 7. 


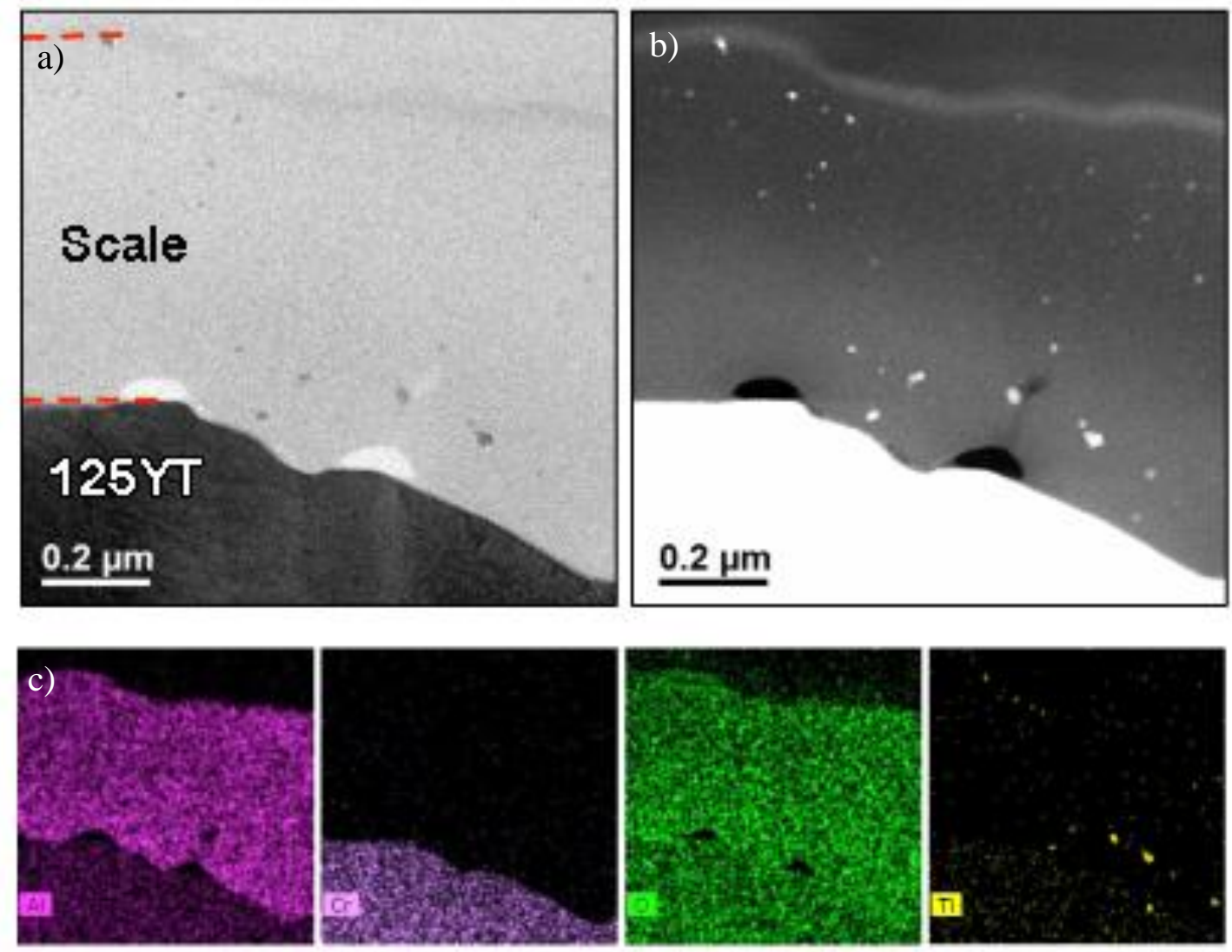

Figure 8. 

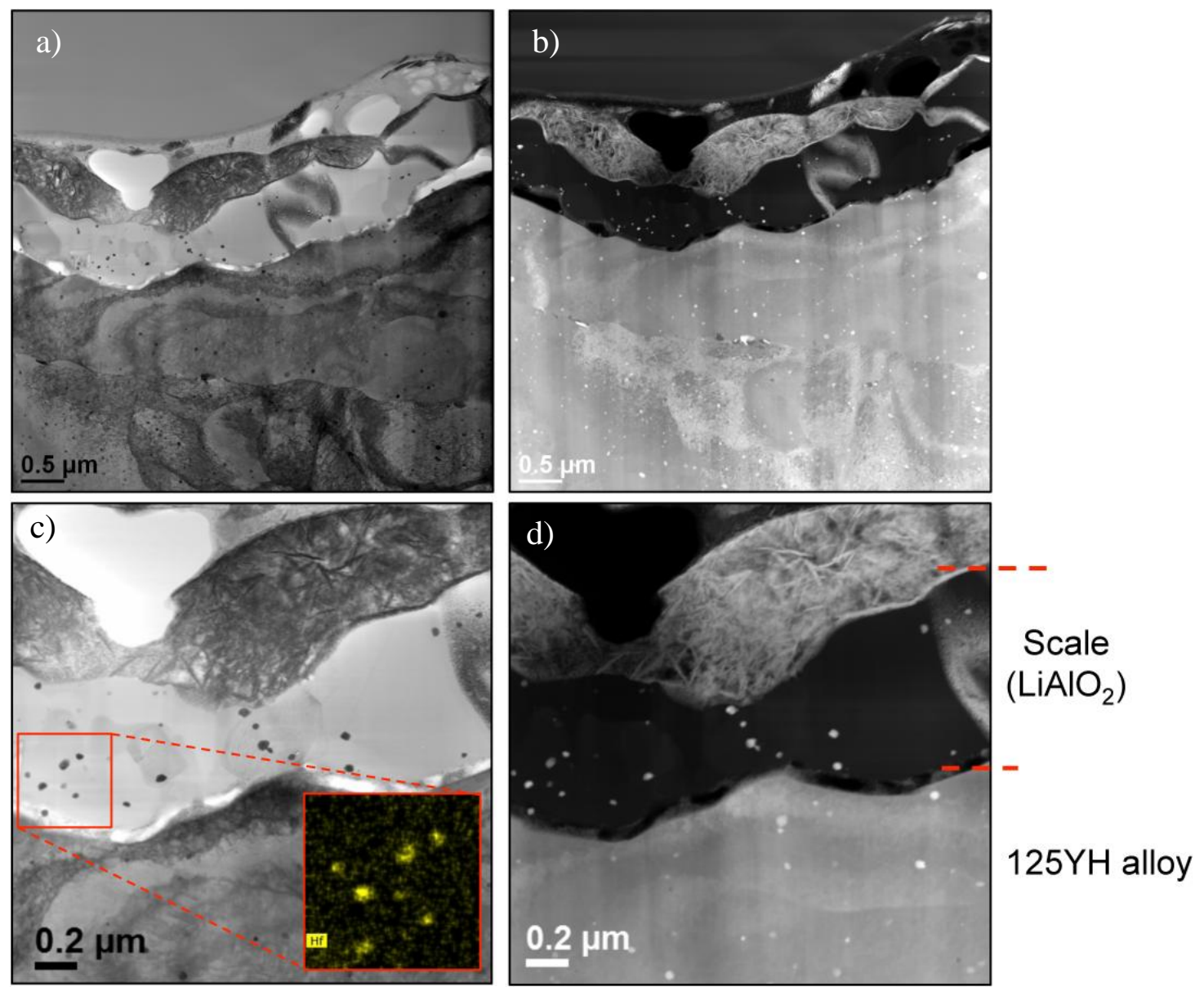

Figure 9. 